\title{
構造物沿いにステム波が形成される波浪場における 入射波の不規則性，多方向性の影響
}

\section{1. まえがき}

外海の大水深域での大規模な構造物のように, 隅角部 を有する構造物に対して平行に近い角度で斜め入射波が 作用する際の構造物前面の波浪場においては，入射角が 小さく，かつ構造物沿いの伝播距離が長いために構造物 沿いの波高増加，波高変動は顕著かつ複雑になるものと 考えられる。

構造物への入射角が小さく，構造物沿いに stem 波が 形成される波浪場についての研究は多くみられる. Wiegel (1964) によると, 入射角が $20^{\circ}$ 以下の規則波が作 用する直立壁前面の波浪場においては Mach-stem が形 成されることが実験的に確認されている。また森屋ら （1995）は，直立壁に斜め規則波が作用し stem 波が形成 されている波浪場を対象とし，実験值との比較検討に よって，構造物沿いの波高分布については，非線形性を 含み浅海域での回折現象を表せるブシネスク方程式が十 分適用可能であるとしている。

しかし，構造物への入射角が小さい波浪場での構造物 沿いの波高分布および斜め入射波の反射特性における入 射波の不規則性，多方向性の影響についてはまだ検討さ

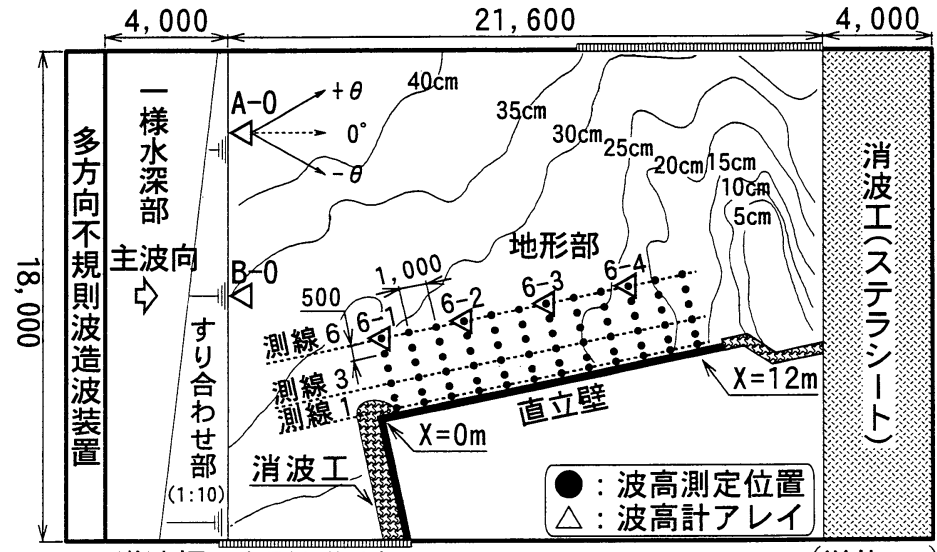

導波板 透過性導波板
(単位: mm)
$*$ 正会員 工修 関西電力(株) 総合技術研究所

**フェロー 工博 京都大学教授 工学研究科 土木工学専攻
れていない.

当研究では，隅角部を有し伝播距離が長い構造物（入 射波の波長の約 5 倍）に対してほほ平行に近い角度で斜 め入射波が作用する波浪場を対象とする，隅角部からの 回折散乱波の影響による波高増加，構造物沿いの stem 波の形成などの波浪場特性について検討し，そこでの入 射波の不規則性，多方向性の影響について評価する。

\section{2. 実験装置および模型}

地形と構造物の模型平面図を図一1に示す．直立壁に 平行に近い角度（約 $10^{\circ}$; 直角入射を $90^{\circ}$ とする）で斜め 入射波が作用し，直立壁前面においては入射波，直立壁 からの反射波，および隅角部からの回折散乱波が共存す る波浪場となる. 平面水槽には 60 枚の造波板(幅 $30 \mathrm{~cm} /$ 枚)から成る多方向不規則波造波装置が設置されている. 入射波が地形モデルに到達するまでにエネルギーが拡散 することを防止するため造波装置の両端から導波板を設 置しているが，直立壁からの反射波が導波板で再反射す ることの防止のために一部については透過性導波板とす る. 直立壁の天端高は当研究での波浪条件において越波 現象が生じない高さとした。

\section{3. 造波した実験波の特性}

5 種類の単一方向不規則波（ケース $1 \mathrm{U} \sim 5 \mathrm{U}$; 各々, 有義波高が $2.5 \mathrm{~cm}$, $5.0 \mathrm{~cm}, 7.5 \mathrm{~cm}, 10.0 \mathrm{~cm}, 14.1 \mathrm{~cm}$, 有義波周期はすべて $1.73 \mathrm{sec})$, 規則波 （ケース $1 \mathrm{R} \sim 5 \mathrm{R}$; 同一の波高，周 期)，および有義波高，有義波周期，主 波向の等しい多方向不規則波（ケース $1 \mathrm{M} \sim 5 \mathrm{M})$ を用いる. 周波数スペクト ルは Bretschneider-光易型, 多方向不 規則波の方向関数は光易型 $\left(S_{\max }=\right.$ 25), 主波向は造波装置と直角方向とし た. 多方向不規則波の造波信号は工ネ ルギー等分割のダブルサンメーション 法によって，周波数 1,024 個，波向き 91 個の成分波を合成して計算した。造 
波した実験波を検定するために，地形開始部付近に造波 装置の中心を含む 2 箇所 (A-0, B- 0 ; 図-1 参照) に 4 本の波高計で構成された波高計アレイを設置し，波高， 周波数スペクトル，方向スペクトルを算定した．多方向 不規則波 (ケース $2 \mathrm{M}, 5 \mathrm{M}$ ) についての方向スペクトル (ベイズ法による解析) を図一 2 に示すが，目標とする方 向スペクトルを有する実験波がほぼ造波できていること が確認できる.なお, 他の実験波についても目標の実験 波が造波できていることを確認した。

\section{4. 構造物沿いの波高分布特性}

著者ら（1998）はすでに当波浪場について規則波，単 一方向不規則波での波高分布特性を比較検討した.ここ でも後の議論のために簡単に紹介する.

規則波，単一方向不規則波の波浪場においては，回折 散乱波の影響もあり, 隅角部から離れるにつれて構造物 沿いでの波高が連続的に増加する，単一方向不規則波に ついて，各波浪条件（ケース $1 \mathrm{U}$ ケケース $5 \mathrm{U}$ ) での直立 壁沿い(測線 1 ) の波高比分布を図一 3 に示す。なお, 波 高比は地形開始部 (B-0：図一1参照) との比率で表す. ここでは, いずれの波浪条件においても隅角部から離れ
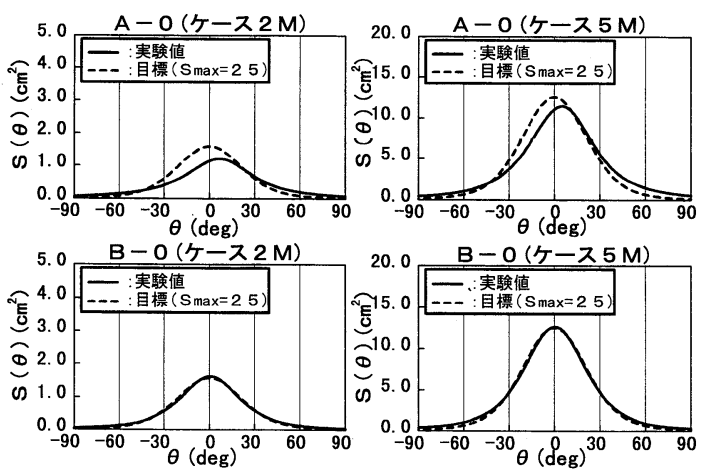

図一2 地形開始部の方向スペクトル（ケース $2 \mathrm{M}, 5 \mathrm{M})$

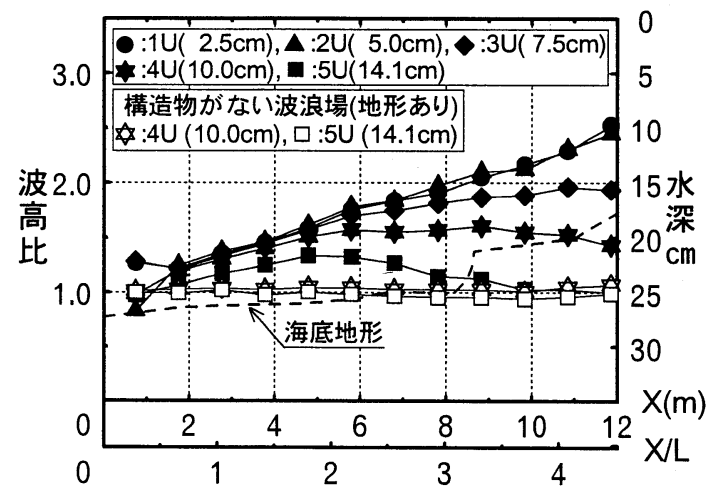

図一3 直立壁沿いの波高比の変化 (単一方向不規則波；測線 1)
るにつれて波高が連続的に増加する傾向がみられ，ケー ス $1 \mathrm{U}, 2 \mathrm{U}$ では隅角部から最も離れた付近 $(X=12 \mathrm{~m}$ 付 近)で地形開始部での波高の約 2.5 倍にも増加する.入射 波の波高の大きいケース $3 \mathrm{U}, 4 \mathrm{U}, 5 \mathrm{U}$ にいては隅角 部から離れるにつれて波高増加が顕著でなくなる傾向が あるが,これは斜め入射波が砕波することの影響であり， 砕波限界波高に達するまでは, 各波浪条件ともに斜め入 射波が同様に発達していく傾向が確認できる，なお，単 一方向不規則波の波浪場での斜め入射波の発達における 地形の影響（屈折, 浅水変形）を把握するために, 構造 物がない波浪場での測線 1 に対応する位置での波高比分 布（ケース $4 \mathrm{U}, 5 \mathrm{U}$ ) も図-3 に示すが，ここでは砕波 が発生せず, 隅角部から離れるにつれての波高増加もみ られない. よって, 斜め入射波の発達における地形の影 響はほとんどないものと考えられる。

次に, 多方向不規則波 $\left(S_{\max }=25\right)$ についての波高比分 布 (測線 1 ) を図一 4 に示す。ここでは規則波，単一方向 不規則波の波浪場とは大きく傾向が異なり，斜め入射波 の砕波の有無にかかわらず，いずれの波浪条件において も隅角部から離れるにつれて波高が増加していく傾向が みられない。

\section{5. 構造物沿いの波高分布特性における入射波 の不規則性, 多方向性の影響}

ケース 1，2，5について構造物沿い（測線 1）での 波高比分布（空間分布）を図一5に示す.

構造物沿いで砕波が発生しない波浪場 (ケース $1 \mathrm{U}, 1$ R, $2 \mathrm{U}, 2 \mathrm{R})$ において, 規則波と単一方向不規則波の波 高分布を比較すると両者の波高比はほほ等しく，入射波 の不規則性の影響がほとんどあらわれない.単一方向不 規則波を異なる周期の規則波の重ね合せと考えると，単 一方向不規則波の波浪場においては波高の空間分布が平 滑化されるために，規則波よりも波高分布が小さくなる

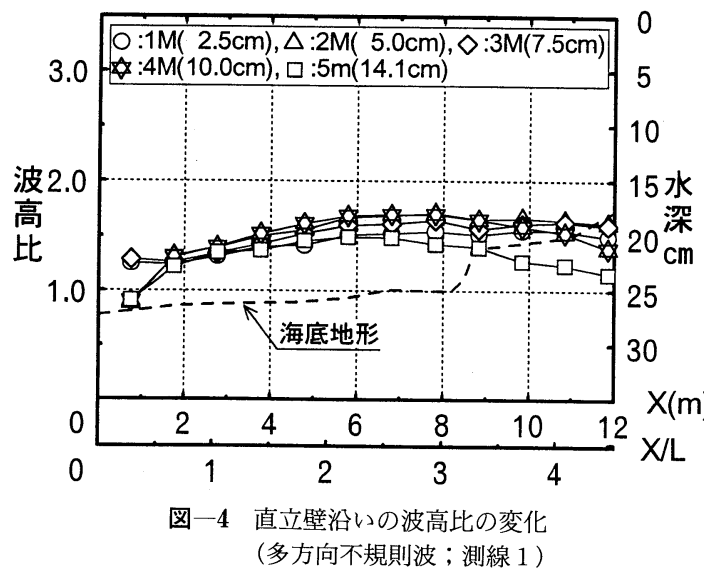

(多方向不規則波；測線 1) 
結果が予想できた。予想と相違したのは, 造波水槽で再 現可能であった $X=12 \mathrm{~m}$ 付近では伝播距離が短く, 規 則波, 単一方向不規則波ともに波高がピーク值に達して いないために両者での違いが小さかったものと考えられ る.ただし，この現象に扔いて入射波の不規則性よりも 方向分散性が支配的要因となっている可能性, つまり方 向分散性のない規則波，単一方向不規則波では 1 波, 1 波の波峰が直線上に長く連なっているために両者が類似 の波高分布特性を示した可能性も否定できない.

これに対して, 入射波の方向分散性が大きい多方向不 規則波の波浪場 (ケース $1 \mathrm{M}, 2 \mathrm{M}$ ) に扔いては, 隅角部 から離れるにつれて波高が連続的に増加していく傾向が みられない。これは，方向分散性を有する多方向不規則 波では回折波成分の位相がずれるために空間分布が平滑 化されたものと考えられる. その結果, $X=12 \mathrm{~m}$ 付近に おいて, 単一方向不規則波での波高比が多方向不規則波 での波高比の約 $1.5 \sim 1.6$ 倍となる.

入射波高が大きく, 構造物沿いで䂶波が発生する波浪 場に扔いては, 上記の傾向が大きく異なる。規則波, 単 一方向不規則波の波浪場（ケース $5 \mathrm{R} ， 5 \mathrm{U}$ ) での砕波が 発生する海域 ( $X>6 \mathrm{~m}$ 付近) では确波による波高低下と ともに, 砕波によって反射波が低減されるために入射波 と反射波の合成による波高増加もほとんどみられない. これに対して, 多方向不規則波の波浪場(ケース $5 \mathrm{M}$ ) で は，構造物沿いの方向成分波が砕波していても異なる方 向成分波が砕波せずに存在するために，砕波が発生する 海域においては規則波, 単一方向不規則波の波浪場より
も波高が大きくなる傾向を示す．ちなみに，入射波と反 射波が重合した規則波の砕波波高が単一波での研波波高 よりも大きいことと同様, 多方向性が砕波波高を増大さ せることが影響している可能性も考えられる.

次に, ケース $1,2,5$ について構造物前面 $1 \mathrm{~m}$ の海 域 (測線 3 )での波高比分布を図一6に示す。構造物沿い で斜め入射波が発達する波浪場(ケース $1 \mathrm{U}, 1 \mathrm{R}, 2 \mathrm{U}$, $2 \mathrm{R})$ においては, 測線 1 ほど顕著ではないものの, 波高

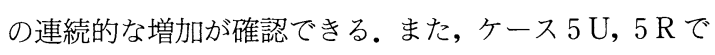
の隅角部から離れた海域 ( $X=9 \mathrm{~m}$ 付近)のように, 測線 1 で砕波が発生しているが測線 3 では砕波が発生してい ない波浪場については, 測線 3 の波高（図一6）が測線 1 の波高(図一5)よりも大きくなる場合もみられる。なお， 多方向不規則波の波浪場に扔いては, 測線 3 の海域でも 斜め入射波の発達はみられないことが確認できる.

\section{6. 構造物前面波浪場での stem 波, 反射波の形 成}

ここでは, 構造物前面波浪場での stem 波 (沿い波) の 形成，反射波の形成について検討する.

Wiegel (1964)によると，入射角が $20^{\circ}$ 以下で規則波が 作用する直立壁前面の波浪場においては, Mach-stem お よび構造物からの反射波が形成されることが実験的に確 認されている.

当研究においても入射波の方向分散性のない規則波お よび単一方向不規則波の波浪場においては，砕波波高に 達するまでは，構造物に沿って stem 波が形成された状
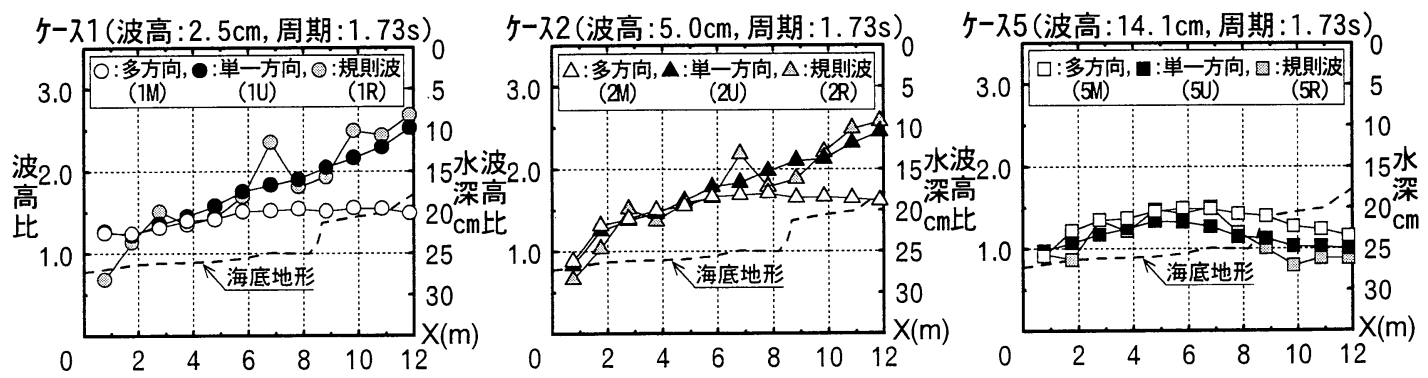

図一5 規則波，単一方向不規則波，多方向不規則波の直立壁沿いの波高比の比較（測線 1 ; ケース $1,2,5$ )
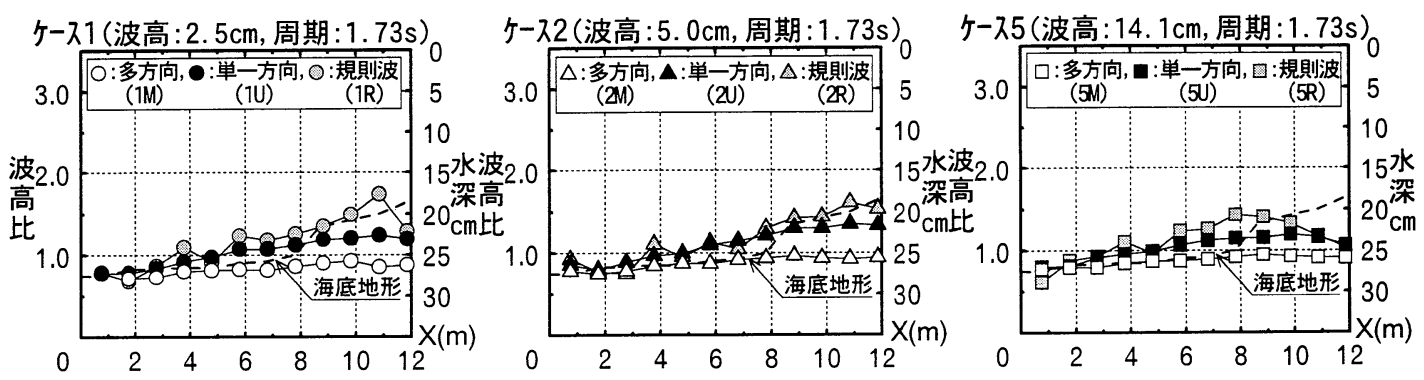

図一6 規則波，単一方向不規則波，多方向不規則波の直立壁沿いの波高比の比較（測線 3 ; ケース $1,2,5$ ) 
態で波高が次第に増加していくことが実験水槽において も確認できる．構造物付近の波峰形状を観察すると，入 射波, 反射波, および構造物沿いの単一波が合わさり $\mathrm{Y}$ 字型をなしてみえるが，この単一波の部分が stem 波で あるといえる.規則波の波浪場 (ケース $2 \mathrm{R}$ )についての 水位の時間変化 $(X=12 \mathrm{~m}$; 測線 $1 \sim 4)$ を図一7 に示 す. 測線 1,2 において急峻なピークをもつ波動が生じ ており, 構造物沿いでは stem 波が形成されていること が確認できる.また, 構造物より約半波長離れた海域で ある測線 4 付近においては波高が小さくなる傾向が確認 できたが(著者ら，1998), 測線 4 での水位変動が入射波 と反射波の 2 つのピークをもつ双峰型となることからも 反射波が形成されていることが確認できる.

これに対して,多方向不規則波が作用する波浪場(ケー ス $2 \mathrm{M})$ においては, stem 波の形成, 構造物沿いの波高 増加はともにみられない.

次に, 構造物沿いで砕波が発生する波浪場での反射波 の形成については入射波の多方向性が大きく影響する。 ケース $5 \mathrm{M}, 5 \mathrm{U}, 5 \mathrm{R}$ での波高比分布を図-8 に示す. 規 則波 (5 R), 単一方向不規則波 (5 U) の波浪場での構造 物沿いで砕波が発生する海域（ $X>6 \mathrm{~m}$ 付近）において は, 構造物前面より約半波長離れた海域（測線 4 付近） で波高が低下する傾向はみられず，構造物前面で反射波 が形成されていないものと考えられる。これに対し, 多 方向不規則波 (5M) の波浪場においては，構造物沿いで 砕波が発生していても構造物前面より約半波長離れた海 域で波高が低下する傾向がみられる。これは, 多方向不 規則波の波浪場は構造物沿いの方向成分波が砕波してい ても異なる方向成分波が砕波せずに存在しており，それ による反射波が形成されているためと考えられる。ケー ス $5 \mathrm{M}$ の 6-1，6-4（図一1参照）の方向スペクトル形状 を図-9 に示すが 6-4での方向スペクトル形状からも， 屈折の影響をうけた入射波のピーク波向 (-10付近) お よび反射波の伝播方向 (+30付近)の 2 方向を中心に工 ネルギーが分布していることが確認できる.

\section{7. 構造物沿いの $1 / 10$ 最大波高の比較検討}

構造物沿いでの砕波が発生していない波浪場の波高分 布特性（有義波高で検討）において，入射波の多方向性 の影響は斜め入射波の発達の有無として確認できた.し かし，多方向不規則波の波浪場においても，単一方向不 規則波と同一方向成分波, つまり構造物に平行に近い方 向成分波については斜め入射波の発達がみられる可能性 が考えられ，1/10 最大波高について検討すれば, 隅角部 から離れるにつれての波高増加がみられる可能性が考え られる.そこで, ケース $2 \mathrm{M}, 2 \mathrm{U} て ゙ の$ 構造物沿い(測線 1) の $1 / 10$ 最大波での波高比分布を $H_{1 / 3}$ での波高比分
布とともに図一10に示す.なお, $H_{1 / 10}$ の波高比は地形開 始部での $H_{1 / 10}$ との比率で表す.

その結果, 多方向不規則波の波浪場においては $H_{1 / 10}$ に ついても隅角部から離れるにつれて連続的に増加する傾 向はみられない. 単一方向不規則波と同一方向の方向成 分波の構造物沿いの発達があるとしても, 結果的には $H_{1 / 10}$ にもその影響があらわれないことが確認できる.

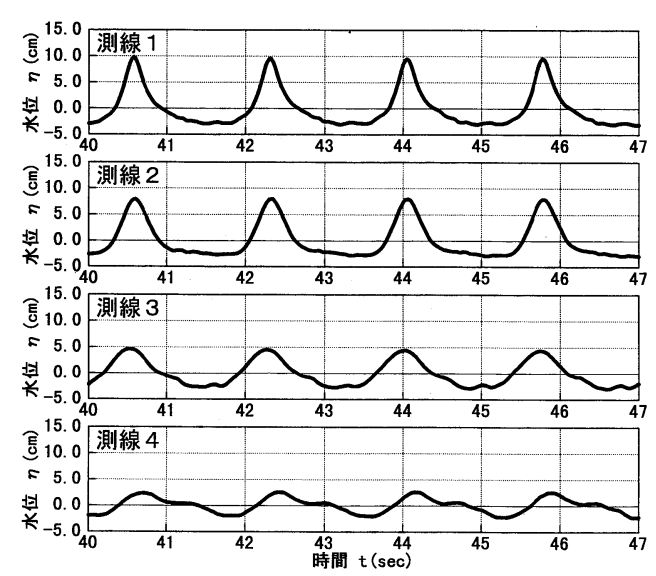

図一7 規則波の水位の時間変化（ケース $2 \mathrm{R} ; X=12 \mathrm{~m}$ )

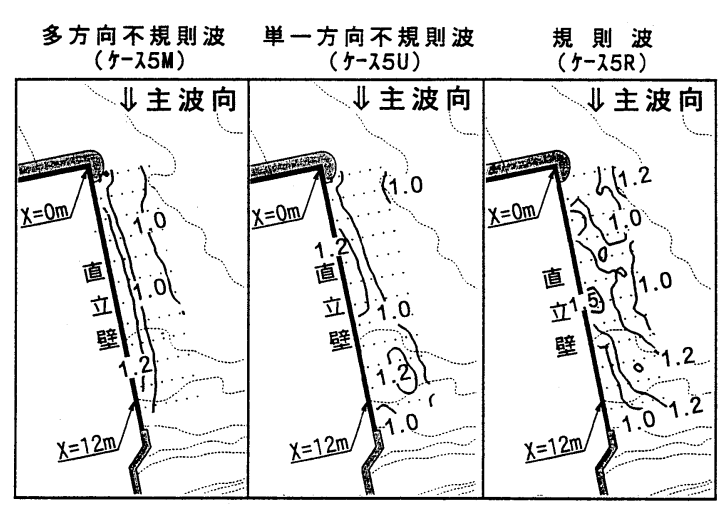

図一8 波高比分布図 (ケース $5 \mathrm{M}, 5 \mathrm{U}, 5 \mathrm{R}$ )

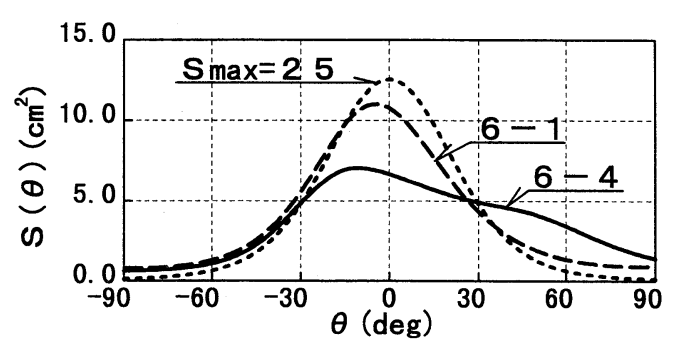

図一9 方向スペクトル（ケース $5 \mathrm{M} ； 6-1,6-4)$ 


\section{8. 数値計算との比較}

Berger ら（1976）は，規則波が作用する直立壁前面の 波高分布について実験值と計算値 (ヘルムホルツ方程式) を比較検討し, stem 波が形成される波浪場の構造物沿い での波高増加は回折現象として説明できるとしている.

ここでは, ヘルムホルツ方程式を解く三井の方法（三 井ら，1967）を用いて構造物沿いの波高分布を算定し， 実験結果と比較検討する。三井の方法では隅角部位置で の入射波の条件より，水深一様として，反射波，隅角部 からの回折散乱波を考慮した計算を実施できる，三井の 方法は規則波を対象としたものであるが，ここでは不規 則波の成分波ごとに計算した結果を合成することによっ て，不規則波での波高比を算定する，入射波の周波数ス ペクトルについては Bretschneider-光易型 (10 分割; エ ネルギー等分割), 方向関数については光易型 (45 分割; 等分割)に設定する。また，隅角部位置の入射波の波高， 波向は構造物がない条件での改良エネルギー平衡方程式 （高山ら，1991）の計算結果より決定する.

構造物沿いで砕波が発生しない波浪場(ケース $2 \mathrm{M}, 2$ U) の計算值を実験值とともに図一11 に示す。その結果, 多方向不規則波の波浪場においては，実験值と計算結果 が比較的よく一致する. しかし, 波高が連続的に増加す
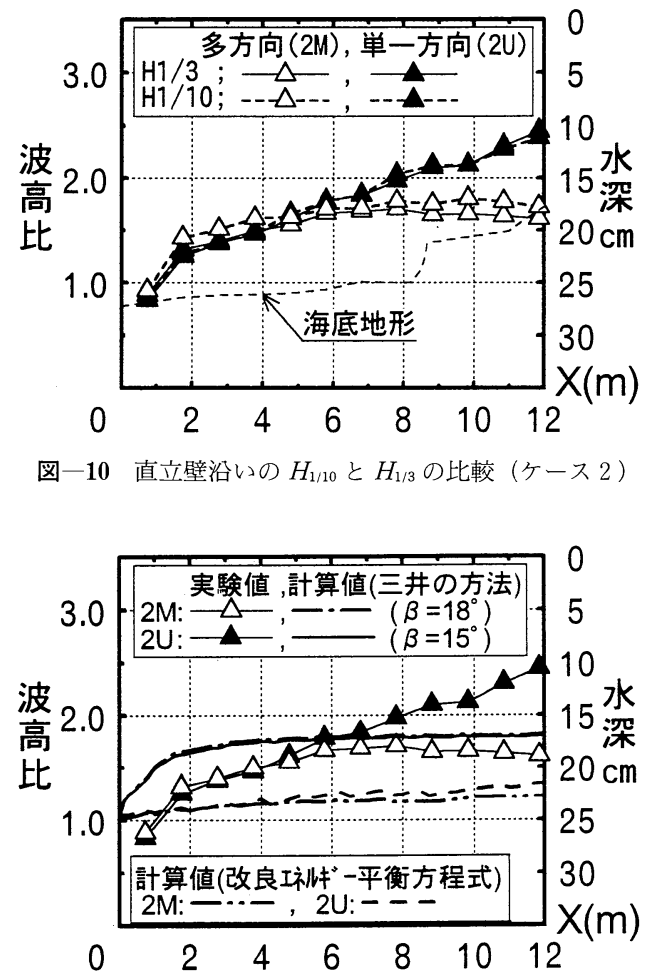

図-11 実験值と数値解析との比較（ケース 2)
る単一方向不規則波の波浪場においては，隅角部から離 れるにつれて実験值よりも計算結果が小さくなる傾向を 示す。これには，三井の方法において考慮できない非線 形性が影響している可能性が考えられる。

また，改良エネルギー平衡方程式による計算結果をと もに図-11 に示すが, 実験結果での斜め入射波の発達が 計算結果ではみられない，入射波と反射波の位相干涉， 回折散乱波を考慮できない点が，当波浪場での構造物沿 いの波高分布特性の評価には適さないといえる.

\section{9. 結 語}

構造物にほぼ平行に斜め入射波が作用し，規則波，単 一方向不規則波では構造物沿いに stem 波が形成される 波浪場を対象として，多方向不規則波を用いた水理模型 実験を併せて実施し，入射波の不規則性，多方向性の影 響について考察した。その結果，入射波の不規則性の影 響はあまりあらわれないが，多方向性の影響が大きくあ らわれた. 構造物沿いで砕波が発生しない場合, 規則波, 単一方向不規則波の波浪場では斜め入射波の発達, stem 波の形成が顕著にみられるのに対し，多方向不規則波の 波浪場ではみられない。また，構造物沿いで砕波が発生 する場合，規則波，単一方向不規則波の波浪場では反射 波が低減されるのに対し，多方向不規則波の波浪場では 異なる方向成分波が砕波せずに存在しているために，規 則波，単一方向不規則波よりも波高が大きくなる.

今後, 構造物への入射角の違いによる波浪場特性の把 握が必要と考えられる。

最後に，計測にあたっては（株）日本工業試験所 内西博氏，数值計算にあたっては（株）二ュージェック 殿最浩司氏の協力を得ました。ここに記して謝意を表し ます。

\section{参 考 文 献}

高山知司・池田直太・平石哲也（1991）：砕波扔よび反射を考慮 した波浪変形計算，港研報告，第 30 巻，第 1 号，pp. 21-67.

三井 宏・村上仁士 (1967)：海岸構造物不連続部の波高分布に ついて(第 2 報)，第 14 回海岸工学講演会論文集，pp. 53-59.

目見田哲・酒井哲郎 (1998)：構造物にほぼ平行に入射する不規 則波による構造物沿いの波高分布特性，海洋開発論文集，第 14 巻 (印刷中).

森屋陽一・菊地正行・松立博樹・水口 優 (1995)：浅海域にお ける周期波のマッハ反射について，海岸工学論文集，第 42 巻, pp. 6-10.

Berger, U. and S. Kohlhase (1976): Mach-reflection as a diffraction problem, Proc. 15th Conf. Coastal Eng., ASCE, pp. 796-814.

Wiegel, R. L. (1964): Water wave equivalent of Machreflection, Proc. 9th Conf. Coastal Eng., ASCE, pp. 82-102. 